\section{ON SOME RECENT RESULTS WITH THE TOWING NET ON THE SOUTH COAST OF IRELAND *}

\section{I.-Mitraria}

ONLY a single specimen was obtained of the little Mitraria, which formed the subject of the present communication, and neither its structure nor development was made out as completely as could have been wished. From the Mediterranean species described in a former communication (British Association Report for 1872 ), it differs in some points of structure and in the mode of annulation of the developing worm. It possesses the usual Mitraria form, that of a hemispherical dome having its base encircled by a band of long vibratile cilia. In the side of the dome a little above the ciliated band is the mouth which leads into a rather wide pharynx clothed with a ciliated epithelium. The pharynx runs through the dome parallel to its base and opens into a capacious stomach which continues in the same direction until it joins the intestine. This then turns down abruptly at right angles to the previous portion of the alimentary canal, and then projects for a slight distance beyond the base of the dome, carrying with it hernia-like the walls of the base.

The true body walls of the future worm, of which the Mitraria is the larva, seem as yet confined to the intestinal segment of the alimentary canal. They already present the commencement of annulation, which, however, exists only on the dorsal and ventral sides, while two broad bands of very distinct fibres may be seen, one on the right and the other on the left side, extending transversely from the dorsal to the ventral surface.

The ciliated band which runs round the base of the dome possesses a rather complex structure. It consists of two concentric rings : an outer one composed of large oval distinctly nucleated cells, and an inner one of a granular structure and yellowish colour, in which no distinct cells could be demonstrated. The cilia form two concentric wreaths borne by the under stde of the band, an outer wreath consisting of very long cilia, and borne by the inner edge of the outer portion of the band, and an inner wreath of much shorter cilia borne by the inner edge of the inner portion. The band with its cilia is interrupted for a very short space at the aboral side of the dome. There is probably at this spot an entrance into a watervascular system. No such system, however, was observed in the specimen, though the author had described in another species of Mitraria a system of sinuses which appear to exist in the walls of the dome, and which he regarded as representing ${ }^{*}$ ? watervascular system (Brit. Assoc. Report for 1872).

Occupying the very summit of the dome is a large, somewhat quadrilateral ganglion, from which two distinct filaments are sent down, one on each side of the alimentary canal, but he was not able to follow these filaments to their destination. The bilateral symmetry of the ganglion suggests its formation out of two lateral halves. Though its very superficial position gives it the appearance of being a mere thickening of the walls, the view here taken of its being a nervous ganglion seems to be the only one consistent with its relations to the surrounding parts.

On each side of the pharynx, a little behind the mouth, is a small oval ganglion-like body from which a filament runs to the ciliated band. Some delicate filaments may also be seen lying between the pharynx and the walls of the dome on which they seem to be distributed, but the author could not trace them to any distinct ganglionic centre.

The great apical ganglion carries two very obvious black ocelliform spots, and besides these two clear vesicles enclosing each a clear spherical corpuscle. The two vesicles may probably be regarded as auditory capsules.

The further development of this larval form has not been observed. It probably consists chiefly in the continued prolongation of the alimentary canal beyond the base of the hemispherical dome, the completion of the annulation by its extension to the right and left sides, and the gradual contraction of the dome and final absorption of the ciliated band.

$$
\text { 2. - Tornaria }
$$

Two specimens of the larval form originally discovered by Johann Miiller, and described by him under the name of Tornaria, were obtained, but these unfortunately perished before a sufficiently exhaustive examination of them could be made. On the whole their structure agrees closely with what has been * Paper read at the Meeting of the British Association, Bradford by Prof. Allman, F.R.S. pointed out by Alex. Agassiz in his valuable and elaborate memoir on Tornaria and Balanoglossuss. The species appears to be different from those hitherto described. The gills had not begun to show themselves, and there were but traces of the "lappets" described in other species as appended to the posterior extremity of the stomach.

The author believed that he could distinguish a minute ganglion on each side of the œsophagus ; filaments were sent off from it to the neighbouring parts, and the two were connected to one another by a sub-œesophagal commisure. The water-vascular chamber was very distinct, but the so-called heart was not observed; while within the body-cavity, lying close to the dorsa pore and over the canal by which the great water-sac communicates with the external medium, was a small, closed, rather thick-walled vesicle containing numerous oval corpuscles. Of the nature of this vesicle the author could not offer any opinion.

The cushion-like body which occupies the summit of the larva exactly as in Mitraria, and supports the two ocelliform spots, was very distinct, and so also was the contractile chord which extends from this to the walls of the water-sac. The author, however, could not here, any more than in Mitraria, regard the cushion-like body as a mere thickening of the walls; he believed it to be a nerve-mass, and thought he could trace two fine filaments proceeding from it and running down, one towards the right and the other towards the left side of the alimentary canal, but he was not able to follow them for any distance, and he does not regard their existence as confirmed. The extremely superficial situation of this body, which makes it resemble a mere thickness of the walls, is paralleled by that of the great ventral nerve-mass in Sagitta.

The contractile chord which runs to the water-sac is probably attached to a capsular covering of the ganglion, rather than directly to the ganglion itself. This chord, though showing strong contractions by which the summit of the larva is drawn down towards the water-sac, is of a homogeneous structure, presenting no appearance of distinct fibrillæ or of other contractile elements.

The author instituted a comparison between Tornaria and Mitraria. We have in both the external transparent pyramidal or dome-shaped body, with a lateral oral orifice, and a basal anal orifice, enclosing an alimentary canal which is divisible into three regions, and takes a partly horizontal and partly vertical direction in its course from one orifice to the other ; * we have in both, near the base of the body, the circular band which carries long vibratile cilia accompanied by a row of pigment spots, and in both the cushion-like ganglion carrying ocelli.

From Mitraria, Tor aria chiefly differs in the presence of the thick sinuous and convoluted bands which give it so close a resemblance to certain Echinoderm larvæ, and which are entirely absent from Mitraria, and in its water-vascular system with the contractile cord which extends from this to the apical ganglion. If a water-vascular system is present in Mitraria, it consists there of a system of sinuses excavated in the walls of the dome, but without any representative of the great central sac. In Mitraria the great apical ganglion carries not only the two ocelli, but also two capsules, probably auditory ; these capsules do not exist in Tornaria. In Mitraria the two nerve chords which the apical ganglion sends down one on each side of the alimentary'canal are very distinct ; in Tornaria, if they exist at all, they are by no means obvious. Finally, the ciliary circlet is simple in Tornaria, while in Mitraria it is double.

According to Alexander Agassiz's account of the development of Tornaria into Balanoglossus, the great transverse circlet of cilia becomes, by the elongation of the body, gradually pushed backwards, so as to form the anal ciliated ring of the young worm ; in Mitraria the great ciliary circlet remains unchanged in position, and is probably ultimately absorbed, the worm during its development acquiring a new anal wreath of cilia.

\section{Ametrangia hemispherica (nov. gen. et spec.)}

Among the most abundant products of the towing-net was a little hydroid medusa, remarkable for the want of symmetry in the distribution of its gastro-vascular canals. It is of a hemispherical form, with the base about halt-an-inch in diameter, and provided with very numerous (more than 100) marginal tentacles, which are very extensile, and may at one time be seen floating away to a length of three or four inches and at another coiled into a close spiral against the margin of the umbrella.

* In the species of Mitraria described by $\mathrm{J}$. Müller and by Metschnikeff, both oral and anal orifices are basal, and the alimentary canal presents a $U$ shaped curvature 
Each tentacle originates in a bulbous base with a distinct ocellus. No lithocysts are visible on the margin. The velum is of moderate width.

The manubrium forms a small projection from the summit of the umbrella, and terminates in four rather indistinct lips. From the base of the manubrium three rather wide offsets are sent off at equal intervals into the walls of the umbrella. These gradually contract in diameter, and then, as three narrow tubes of uniform diameter, run towards the margin, where they open into the circular canal. The symmetry of the radiating canals is confined to these three primary trunks. From their wide proximal ends each sends off branches, some of which may be traced to the margin where, like the three primary canals, they enter the circular canal, while others can be followed for various distances in the umbrella walls, in which they terminate by blind extremities without ever reaching the margin. These branches are very irregular in the number sent off from each primary canal, as well as in their length and directions.

The generative elements are formed in oval sporosacs developed one on each of the three primary canals at the spot where the wider base passes into its narrower continuation. The ova may be seen within them in various stages of development; they increase considerably in size before the commencement of segmentation, always showing up to that period a large and distinct germinal vesicle with germinal spot and with a distinct nucleolus in the interior of the germinal spot. The development of the ovum proceeds within the sporosac to the segmentation of the vitellus and the formation of the planula, which now breaks through the outer walls of the sporosac and remains for some time adhering to their external surface. The planula differs remarkably from the typical hydroid planula. It remains of a nearly spherical form, never acquiring cilia, and possesses little or no power of locomotion. The gastric cavity, however, is fully formed. The author was unable to follow the ova in their further development.

The little medusa now described, cleparts in several important points from the typical hydroid medusa. From this it differs in the ternary disposition of the primary radiating canals, and in the irregular non-symmetrical arrangement of those which are subsequently formed. Among the very many specimens examined, the author never found any in which the canals had become regular in their disposition, even in those which had discharged the contents of their sporosacs, and had evidently attained the term of their existence. It differs also from the typical medusa in the form and non-ciliated condition of the planula; and still further in the fact that while the generative elements are borne on sporosacs, developed on the radiating canals, the marginal bodies are ocelli and not lithocyst.

$$
\text { 4.-Circe invertents (nov, spec.) }
$$

Among the hydroid medusæ captured in the towing-net, were two or three specimens of a species referable to the genus Circe of Mertens. It measures about half-an-inch in its vertical diameter, and about a quarter of an inch transversely. It is cylindrical from its base upwards, for about two-thirds of its height, and then contracts abruptly, and arches dome-like towards the truncated summit, which is surmounted by a solid cone of the gelatinous umbrella substance. From the summit of the umbreila-cavity, a solid somewhat fusiform extension of the roof hangs down in the axis of its cavity for about two-thircls of its depth, and at its free end carries the manubrium, which extends nearly to the codonostome. The margin of the umbrella carried eighty very short and but slightly extensile tentacles, which were connected at their bases by a very narrow membraneous extension of the margin, with rather irregular free-edge. Lithocysts are situated at irregular intervals upon the margin. There are about sixteen of them; they consist each of a minute spherical vesicle with a single large spherical concretion. There are no ocelli. There is a moderately wide velum.

The radiating canals are eight in number. They spring from the base of the manubrium, run up the sides of the solid process which hangs from the summit of the umbrella; pass from this to the walls of the umbrella, and then run down towards the margin in order to open into the circular canal.

The generative elements are borne in pendent sporosacs, which spring from the radiating canals close to the summit of the umbrella cavity.

The motion of the medusa takes place by means of sudden jerks, reminding us of the way in which certain Diphyda dart through the water,
The medusa possesses also a very singular habit of partial inversion. This takes place along the line which separates the dome-like portion of the umbrella cavity from the lower cylin. drical portion, and consists in the withdrawal of this dome-like summit and the lower portion of the cavity. When thus inverted the little animal presents a drum-shaped form, with the manubrium hanging far out of the codonostome.

Alexander Agassiz considers the genus Circe, of Mertens, as synonymous with Trachynema Gegenbaur, and points out that the name of Circe had been already used for a genus of mollusca. He further removes it from among the true hydroid meduse, and regarding it as closely allied to the AEginidce, places it along with those in the Haplostonnea Agassiz, a sub-order of the Diso cophora.

The author, however, could not see sufficient grounds for the removal of Mertens' genus from the true Hydroida, with which the medusa now described agrees in all essential points, including the form and disposition of the gastro-vascular and generative systems and the structure of the marginal lithocysts. Neither could he agree with Alexander Agassiz in identifying it with Trachynema. The greatly developed solid peduncle by which the manubrium in Circe is suspended from the summit of the umbrella-cavity in a way, however, which has its parallel in Tima among others, is of itself a character of generic importance by which Circe must be kept apart from Trachynema. It is true that Gegenbaur's Trachynema has the character of a young form, and until we have further evidence of its adult state its affinities cannot be regarded as established.

Gegenbaur believes that he has established the direct develop* ment of Trackynema from the egg without the intervention of a hydriform trophosome, but unfortunately we have no data by which to compare in this respect Circe with Trachynema.

It must be admitted too that in the imperfect contractility of the marginal tentacles and in the somewhat greater firmness of the umbrella walls the little medusa described in the present communication possesses characters which look towards the

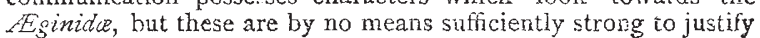
its separation from the ordinary hydroid medusx.

$$
\text { 5.-. Tomopteris }
$$

A few young specimens of this beautiful little worm were obtained, and the author was enabled to confirm the statements of Grube and of Keferstein, who describe in it a double ventral nerve chord, though other observers have failed to discover this part of the nervous system and throw doubt upon its existence. In adult specimens examined some years previously by the author no ventral chord could be detected.

The ventral portion of the nervous system consists of two flat ribbon-shaped chords which are given off from the inferior side of the nerve ring which surrounds the pharynx just behind the mouth. These run parallel to one another, separated by a narrow interval; they lie on the ventral walls of the animal, and may be traced through the narrow taillike termination of the body as far as its extremity. They present no ganglionic swellings, but opposite to every pair of feet each sends off a filament which passes to the foot of its own side in which it is distributed.

Dr. Anton Dohrn has just informed the author that he too had distinctly seen the vextral chord of Tomopteris.

\section{SCIENTIFIC SERTALS}

AMONGST the papers in the October and November numbers of the American Naturalist, are included Dr. J. L. Smith's Address to the American Association for the Advancement of Science, on Science in America and Modern Methods of Science. -Mr. R. Ridgway describes some new forms of American Birds, which he considers as geographical races, and not distinct species. Included are Catherpes mexicanus, var. conspersus; Helminthophaga celata, var. lutescens; Dendroica vieillotii, var. bryanti; D. dominica, var. albilora; $D$. oracia, var. decora; Myiodioctes pusillucs, var. pileolata (Pallas), and Colluirio ludovicianus, var. robustzus (Baird), which are described and followed by a synopsis of the genera of Certhiola, Funco, and Cardinalis. Prof. C. A. Riley has a paper on the Oviposition of the Yucca Moth, in which he shows that the female conveys her eggs into the young fruit by a lateral puncture. The Structure and Growth of Domesticated Animals, forms the subject of a popular lecture by Prof. Agassiz, which is followed by one on Staurolite 